5. Demirkaya E, Consolaro A, Sonmez HE, Giancane G, Simsek D, Ravelli A. Current Research in Outcome Measures for Pediatric Rheumatic and Autoinflammatory Diseases. Curr Rheumatol Rep 2016;18:8.

Received: July 08, 2020 Accepted: July 10, 2020

Online: February 25, 2021
Correspondence: Betul SOZERI, MD. Saglik Bilimleri Universitesi, Umraniye Egitim ve Arastirma Hastanesi, Cocuk Romatoloji Klinigi, Istanbul, Turkey.

Tel: +90 2166507676 e-mail: drbetulsozeri@gmail.com doi: $10.14744 /$ nci.2020.25826

(c) Copyright 2021 by Istanbul Provincial Directorate of Health - Available online at www.northclinist.com

\title{
CORRIGEndum
}

กORTH CLIn IStAnB 2021;8(2):202

doi: $10.14744 /$ nci.2021.15428

\section{The effects of pre-obesity on quality of life, disease activity, and functional status in patients with ankylosing spondylitis}

\author{
(D) Seyma Toy, ${ }^{1}$ () Davut Ozbag, ${ }^{2}$ (i) Zuhal Altay, ${ }^{3}$ () Ahmet Kavakli ${ }^{4}$ \\ ${ }^{1}$ Department of Anatomy, Karabuk University Faculty of Medicine, Karabuk, Turkey \\ 2Department of Anatomy, Inonu University Faculty of Medicine, Malatya, Turkey \\ ${ }^{3}$ Department of Physical Medicine and Rehabilitation, Inonu University Faculty of Medicine, Malatya, Turkey \\ ${ }^{4}$ Department of Anatomy, Firat University Faculty of Medicine, Elazig, Turkey
}

\section{Corrigendum}

North Clin Istanb 2017;4(1):52-59

doi: $10.14744 /$ nci.2017.27122

The list of authors was incomplete in the original publication.

The correct list is:

Seyma Toy, Davut Ozbag, Zuhal Altay, Ahmet Kavakli 